\title{
CLAUDIAN, DE RAPTU PROSERPINAE 1.82 AND GEORGICS 3.68*
}

That Claudian imitates Virgil's Georgics in the De Raptu Proserpinae is well known. Most of his allusions are restricted to Golden Age or Underworld imagery, largely from Books 1, 2, and 4. ${ }^{1}$ However, one imitation of the third Georgic that appears not to have been noted previously occurs at De Raptu Proserpinae 1.82. The context is Claudian's famous description of Pluto enthroned:

\begin{abstract}
ipse rudi fultus solio nigraque uerendus maiestate sedet: squalent inmania foedo sceptra situ; sublime caput maestissima nubes asperat et dirae riget inclementia formae; terrorem dolor augebat.
\end{abstract}

(De Raptu Proserpinae 1.79-83)

I argue that this recalls the following passage in Virgil:

optima quaeque dies miseris mortalibus aeui prima fugit; subeunt morbi tristisque senectus et labor, et durae rapit inclementia mortis.

(Georgics 3.66-8)

Inclementia occurs some twenty times in extant classical and late antique Latin verse. ${ }^{2}$ Claudian himself uses it three other times. Nonetheless, the construction of Claudian's line makes

* I am grateful to Michael Dewar, Catherine Ware, and the anonymous reader for $C Q$ for their comments on an earlier version of this note.

${ }^{1}$ See e.g. A.K. Clarke, 'Claudian's method of borrowing in De Raptu Proserpinae', PCPhS 181 (1950-1), 4-7; O. A.W. Dilke, 'Patterns of borrowing in Claudian's De Raptu Proserpinae', RBPh 43 (1965), 60-1; C. Ware, Claudian and the Roman Epic Tradition (Cambridge, 2012), 171-97.

${ }^{2}$ On the word see further R.G. Austin, P. Vergili Maronis Aeneidos Liber Secundus (Oxford, 1964) on Aen. 2.602, and for Claudian's use of it see M. Dewar, Claudian: Panegyricus de Sexto 
it clear that the line from the Georgics is being imitated here: the lines are metrically equivalent, and the sound-pattern and identical grammatical structure make the imitation unmistakable (I et $d^{-}$rae $r^{--}$inclementia $\left.{ }^{-x}\right)$.

Scholarship on this description of Pluto has emphasised the god's imposing appearance and maiestas. ${ }^{3}$ The focus on the physical appearance of the god is typical of Claudian's poetic technique, which tends towards the descriptive and the visual. ${ }^{4}$ Certainly, dirae riget inclementia formae is a highly physical phrase, inclementia here referring to the harshness of Pluto's appearance. We might compare examples of inclementia being used of either the sky or sea to refer to stormy weather, such as Stat. Theb. 5.173 medii inclementia ponti; Claud. VI Cons. Hon. 445 inclementia caeli; Claud. Goth. 210 maris inclementia. Yet the word is more frequently used in a non-physical sense (Verg. Aen. 2.602 diuum inclementia; Stat. Theb. 11.684 inclementia regum; Avien. Orb. Terr. 549 inclementia fati). Perhaps the closest parallel of all is to be found in Valerius Flaccus, when Jason says to Medea haud tales decet inclementia uultus (7.416): Medea's cruelty is not in keeping with her appearance.

I suggest that Claudian has in mind both senses of inclementia in this line. The physical aspect is to the forefront, to be sure. Yet the allusion to Virgil should remind the reader of the

Consulatu Honorii Augusti (Oxford, 1996) on VI Cons. Hon. 445. H. Gasti, 'Divum inclementia', $C Q 56$ (2006), 629-30, suggests that the phrase at Aen. 2.602 is a translation of $\theta \varepsilon \tilde{\omega} v$ $\alpha \dot{\alpha} \gamma v \omega \mu$ o $u ́ v \eta v$ at Soph. Trach. 1266.

${ }^{3}$ See the excellent comments ad loc. in C. Gruzelier, Claudian: De Raptu Proserpinae (Oxford, 1993), as well as G. Schwarz, 'Nigra maiestas: Bryaxis - Sarapis - Claudian' in G. Schwarz \& E. Pochmarski (edd.), Classica et provincialia: Festschrift Erna Diez (Graz, 1978), 189-210, and T. Kellner, Die Göttergestalten in Claudians De Raptu Proserpinae (Stuttgart, 1997), 244-5.

${ }^{4}$ On Claudian's poetic technique see especially I. Gualandri, Aspetti della tecnica composita in Claudiano (Milan, 1968), A. Fo, Studi sulla tecnica poetica di Claudiano (Catania, 1982), C. Gruzelier, 'Temporal and timeless in Claudian's De Raptu Proserpinae', G\&R 35 (1988), 56-72. 
word's other sense. In the Georgics, Virgil has just spoken of the age at which cows become capable of child-bearing, and in these lines meditates more generally on the fleetingness of life, before 'harsh death' snatches mortals away. And the image of the gloomy Pluto is surely given added depth by reminding the reader of Virgil's tristis senectus - Pluto is all too aware of his status as an aging bachelor, who has missed out on a carefree youth. The severe Pluto resembles a late antique emperor in his rigid appearance: yet this allusion reveals something of the god's emotional state, preparing the reader for the outburst of wounded anger to be seen in his speech at $D R P 1.93-116$.

The British Library

CILLIAN O'HOGAN

cillian.o’hogan@bl.uk 